\title{
四全総と内需 拡大 \\ THE FOURTH COMPREHENSIVE NATIONAL DEVELOPMENT PLAN AND EXPANSION OF DOMESTIC DEMAND
}

大河原 満* ・石 田省 三**

By Mitsuru OHKAWARA and Shouzo ISHIDA

はじめに

第四次全国総合開発計画，い わゆる四全総が昨年の 6 月 30 日 に閣議決定されました.

全国総合開発計画はこれまで 3 回策定されていますが，前回 の三全総が策定されてから 10 年を経, 社会環境もその当時か らかなり変わってきています.

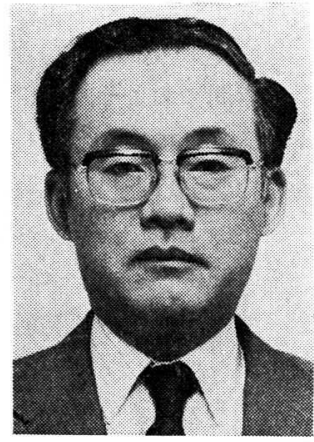

また，三全総が策定されました昭和 50 年代前半には， 人口の大都市集中が終り地方への定着の時代になったか にみえました。

しかし，50 年代半ば以降東京圏への高次都市機能の 一極集中とそれに伴う人口の再集中が生じ, 逆に, 地方 圈では産業の不振等により雇用問題が深刻化し, 人口も 再び減少し始める所が増えています.

一方，が国の経済は世界経済の 1 割を占めるように なり, 国際経済社会との調和への貢献が強く求められる ようになってきました.

このような流れのなかで, わが国経済構造も内需主導 型の経済成長への転換が求められています.

\section{* 正会員 国土庁水資源部長}

（干100 千代田区霞ヶ関 1-2-2）

** 正会員 国土庁計画調整局計画官

Keywords : the fourth comprehensive national development plan, multi-polar pattern of national land use, water and greenery networks, strategic policy projects, national infrastr. ucture investments, expansion of domestic demand

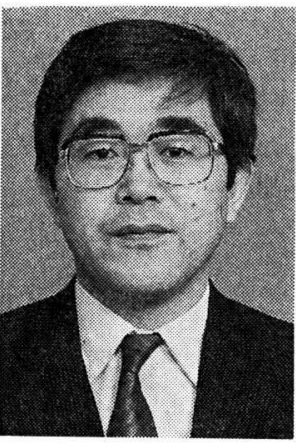

さらに，今後の社会を想定す ると技術革新, 国際化，高龄 化, 国民意識の質的な変化等経 済，社会をとりまく諸情勢の急 激な変化が予想されています.

このような状況に対応し，活 力と創造性に富んだ安全で美し い国土を 21 世紀に引き継ぐた めに，新たな国土計画を策定す ることが必要となってきたわけ です.

四全総は, このような状況を踏まえ, 西歴 2000 年を 見通した長期的な観点に立って, 地域での多様な産業振 興施策の展開, 全国的な交通ネットワークの早期完成, 交流の活発化, 東京を中心とした世界都市機能の集中や 本格的な国際化の進展等のさまざまな課題に適切に対処 するための諸施策の方向, 新しい時代に向けての国土開 発のあり方について示したものです.

\section{1. 四全総の目指す国土の姿}

\section{(1) 計画の目標}

現在, わが国が直面している新たな地域課題と経済, 社会の変化に的確に対応するための, 国土計画における 基本的課題としては次のようなものが挙げられます.

(1) 地域づくりの基礎的条件の整備

近年地方圈では人口減少を生じている地域が増えて おり，これらの地域で就業の場を確保し，地域社会の 発展を担う人材を育成しながら地方の活性化を進める 必要があります。 
(2) 本格的な国際化への対応と世界都市機能の再編成 わが国の国際社会にお括りる地位と役割は非常に大き くなっており, 今後本格的な国際化の時代を迎え，世 界に開かれ，世界と共に歩む国土ゔくりを進めること が求められています.

(3) 安全で美しい国土の形成

都市化，情報化，技術革新等が進展し複雑多様化す る社会で, 国民の安全を確保することは安定した人と 国土のかかわりのための基礎的条件となります.

また，生活水準の向上，自由時間の増大等に伴い国 民ニーズも多様化しており, ゆとりと安心感のある質 の高い地域環境の整備と, 安定したうるおいのある国 土を形成することが重要な課題となっています.

国土の均衡ある発展を図るためには, 行政, 経済, 情 報等の諸機能を東京圈一極で担うのではなく, 多極的に 分担することによって一極集中を是正し, 地方圈を戦略 的, 重点的に活性化することが重要な課題となっていま す.

このような観点から，四全総では「安全でうるおいの ある国土の上に，特色ある機能を有する多くの極が成立 し, 特定の地域への人口や経済機能, 行政機能等諸機能 の過度の集中がなく, 地域間, 国際間で相互に補完, 触 発しあいながら交流している多極分散型国土」を形成す ることを基本的な目標としています.

\section{(2)，交流ネットワーク構想}

国際化, 情報化の進展, 自由時間の増大, 交通利便性 の向上等から, 人々の行動領域は拡大し交流が活発化す る時代を迎えようとしています.

交流の活発化は経済活動範囲を拡大, 活発化し, 自ら の地域の持つ風土や歴史に培われた地域のアイデンティ ティーを涵養し, 地域相互が個性豊かな異質なものに触 れることによって, 社会全体の活性化, 新た なるものの創造を可能とすることが期待され ます。

本計画では，近年各地域で活発化している 多様な交流の動きに着目し，交流の拡大によ る地域相互の分担と連携関係の深化を基本と した，次のような「交流ネットワーク構想」 を推進することにより，多極分散型国土の形 成を図ることを目指しています。

・地域の特性, 創意・工夫を機軸とした定住 と交流の場である地域の整備

・高速交通体系の全国的展開による, 全国主 要都市間で日帰り可能な全国一日交通圈の 構築

・国，地方，民間諸団体の連携による多様な
表一1 交流ネットワーク構想の内容例

(1) 地域が主体となった個性豊かな地域づくり 中枢的都市機能の集積挆点の形成 先端技術産業の集積败点の形成 特色ある農林水産業の掀点の形成 国際交流执点の形成

(2) 地域間の交流を支える高速交通体系等の整備 全国主要都市間で日帰り可能な全国一日交通圈の構築 地方圈における国際交通機能の強化 高度な情報・通信体系の全国展開 長距離通信コストの低減

(3) 交流の機会づくりの推進

都市と農山漁村との広域的交流

産業技術ネットワーク

イベントの共同あるいは持ち回り開催

姉妹都市や地域レへル等での国際交流

交流の機会の形成

（表一1）

\section{(3) 計画のフレーム}

\section{a) 人 口}

昭和 60 年に 1 億 2105 万人になったわが国人口は, およそ 25 年後に 1 億 3600 万人台に達して頭打ちする と予想されています．このような趨勢のもとで四全総の 目標年次である昭和 75 年の人口は, 昭和 60 年からの 15年間に拉よそ 1000 万人増加し 1 億 3120 万人程度と 見込まれています。

地域別の人口は, 昭和 50 年代前半には地方圈への定 住化が進んでいましたが，50 年代後半になり地方圈か らの流出,東京圈一の一極集中の樣相を呈し始めました.

国土の均衡ある発展を図るためには，東京圈への人口 集中を抑制し，地方圈での人口定住を促す必要がありま す.このため，これまでの諸施策に加え交流ネットワー ク構想を柱とする新たな施策を強力に推進し，お打むね 計画期間央に地方圈からの人口純流出を純流入に転ずる ことを目指しています。

総人口の年齢構造は今後急速に高齢化することが見込

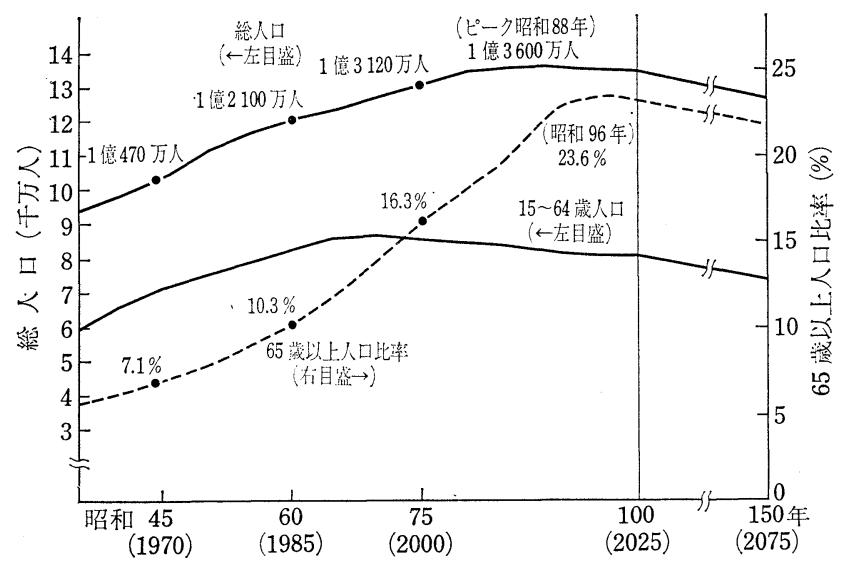

資料: 厚生省人口問題研究所 5 日本の将来推計人口: 昭和 61 年 12 月推訫」

図一1 人口の長期趨勢 
まれており， 65 才以上人口の総人口に占める比率は昭 和 60 年の $10 \%$ 強から 75 年には $16 \%$ 強に達し 2000 万人を超えることとなります.

(図一1)

また，労働力人口は 6650 万人と見込まれています が，やはりその高齢化が進むこととなります。

b）経済・産業と地域の就業

昭和 75 年度の実質国民総生産は, 内需主導による中 成長が維持されることを前提として，お柇むね 500 兆円 台と想定しています.

この場合, 昭和 61 年度から 75 年度の間に官民あわ せた広義の国土基盤投資（公的固定資本形成，民間住宅 投資㧍よびエネルギー，交通，情報・通信，都市再開発 等にかかる民間企業設備投資）の累積額 は，㧤打むね 1000 兆円程度になるものと想定されています.

産業構造はニーズの高度化，多様化を背景に第三次産 業なかでもサービス産業の成長が相対的に高くなり，第 一次, 第二次産業の比率がその分下がるものと見込まれ ています.

職業構造の面からみると, 昭和 45 年に就業者の半数 以上を占めていた農林漁業職や製造工程作業職など物の 生産に從事する直接生産職の人々の比率が, 昭和 75 年 には $35 \%$ 程度になる一方, 事務職, 販売職, サービス 職等に從事する間接生産職の人の占める割合が一段と高 くなります。

たとえば，サービス業に従事する人は昭和 60 年の 1192 万人から 600 万人程度増加するものと想定されて います，そのうち，情報処理等のビジネス関連サービス に従事する人は約 430 万人増加するものと見込まれてい ます。

c）交流

今後, 本格的な国際交流の時代を迎え, 世界との人的

・物的交流，投資交流の増大が見込まれています。

国内についても交通基盤整備等により, 地域間交流の 自由度が高まり交通量は増加します。

また，新たな情報・通信メディアによるものを中心と して，情報交流が一層活発化します。

(表-2)

計画目標年次 (昭和 75 年度) での交流の活発化の状 況を現在と比べてみますと，まず世界との交流について は, 人的交流は海外渡航者が 2.0 2.4 倍, 海外からの 訪日外国人は $2.6 \sim 3.5$ 倍, 日本に常時滞在する外国人 も 2.7 倍と増加することが見込まれています.

物的交流については, 産業の国際化の進展等から輸出 入品の高付加価值化, 軽量化が進むものの, 約 1.2 倍程 度に増加することが見込まれています。

情報交流は国際化の著しい進展, 通信網の高度化等を 背景に 20 倍と大幅に増加することが見込まれています。 企業の海外生産比率も昭和 59 年度の $4.9 \%$ から 1 割

\begin{tabular}{|c|c|c|c|c|c|c|c|}
\hline & \multicolumn{2}{|c|}{ 項 } & 目 & 昭和 60 年度 & $\begin{array}{l}\text { 構成比 } \\
(\%)\end{array}$ & 昭和75年度 & $\begin{array}{l}\text { 構成比 } \\
(\%)\end{array}$ \\
\hline $\begin{array}{l}\text { 国 } \\
\text { 際 } \\
\text { 交 } \\
\text { 流 }\end{array}$ & \multicolumn{3}{|c|}{ 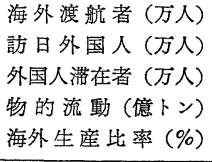 } & $\begin{array}{r}490 \\
230 \\
22 \\
6.7 \\
4.3\end{array}$ & & $\begin{array}{c}1000 \sim 1200 \\
600 \sim 800 \\
60 \text { 万人以上 } \\
8.1 \\
10 \% \text { 以上 }\end{array}$ & \\
\hline & \multicolumn{3}{|c|}{ 日交流可能人口人) } & 4700 & & 5900 & \\
\hline 国 & 旅 & $\begin{array}{l}\text { 輸 } \\
\text { 送百 } \\
\text { 人员 } \\
\text { 員万 } \\
\text { 人 }\end{array}$ & $\begin{array}{lr}\text { 総 } & \text { 計 } \\
\text { 自 } & \text { 動 } \\
\text { 鉄 } & \text { 道 } \\
\text { 海 } & \text { 運 } \\
\text { 航 } & \text { 空 }\end{array}$ & $\begin{array}{r}53866 \\
\\
34679 \\
18989 \\
154 \\
44\end{array}$ & $\begin{array}{r}100.0 \\
64.4 \\
35.2 \\
0.3 \\
0.1\end{array}$ & $\begin{array}{c}69000 \\
\sim 72000 \\
49000 \\
22000 \\
140 \\
94\end{array}$ & $\begin{array}{l}100 \\
69 \\
31 \\
0.2 \\
0.1\end{array}$ \\
\hline 内 & 客 & 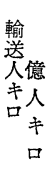 & $\begin{array}{ll}\text { 総 } & \text { 計 } \\
\text { 自 動 } & \text { 車 } \\
\text { 鉄 道 } \\
\text { 海 } & \text { 運 } \\
\text { 航 空 }\end{array}$ & $\begin{array}{r}8582 \\
4893 \\
3301 \\
57 \\
331\end{array}$ & $\begin{array}{r}100.0 \\
56.9 \\
38.5 \\
0.7 \\
3.9\end{array}$ & $\begin{array}{c}11000 \\
\sim 12000 \\
7200 \\
3900 \\
52 \\
700\end{array}$ & $\begin{array}{c}100 \\
61 \\
33 \\
0.4 \\
6\end{array}$ \\
\hline 交 & 貨 & 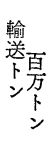 & $\begin{array}{ll}\text { 総 } & \text { 計 } \\
& \\
\text { 自 } & \text { 動 } \\
\text { 軼 } & \text { 道 } \\
\text { 海 } & \text { 運 }\end{array}$ & $\begin{array}{r}5048 \\
99 \\
452\end{array}$ & $\begin{array}{r}90.1 \\
1.8 \\
8.1\end{array}$ & $\begin{array}{c}6500 \\
\sim 7700 \\
6500 \\
74 \\
520\end{array}$ & $\begin{array}{r}100 \\
92 \\
1 \\
7\end{array}$ \\
\hline 流 & 物 & 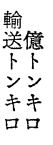 & $\begin{array}{lr}\text { 総 } & \text { 計 } \\
& \\
\text { 自 } & \text { 動 車 } \\
\text { 鉄 } & \text { 道 } \\
\text { 海 } & \text { 運 }\end{array}$ & $\begin{array}{r}4344 \\
\\
2059 \\
221 \\
2058\end{array}$ & $\begin{array}{r}47.4 \\
5.1 \\
47.4\end{array}$ & $\begin{array}{c}5600 \\
\sim 6500 \\
3200 \\
230 \\
2600\end{array}$ & $\begin{array}{r}53 \\
4 \\
43\end{array}$ \\
\hline
\end{tabular}

注 1）貨物輸送の総計に航空を含む.

2）各機関別の将来值にも，総計と同程度の幅がある.

程度に増加する見込みです。

また，国内についても，21 世紀に向けて国民生活や 経済・社会活動の一層の広域化が進展することにより， 人的交流は拈よそ 1.3〜1.4 倍，物的交流はおよそ 1.2 〜1.5 倍になるものと見达まれています. 情報交流は, 今後各分野においてネットワーク化が急速に進み全国の 総情報交流量は昭和 59 年の約 3 倍, なかでも, データ 通信, ファックス等新たな情報・通信メディアによるも のは，約 20 倍と飛躍的に伸びることが見达まれていま す.

\section{2. 計画実現のための主要施策}

交流ネットワーク構想の推進により多極分散型国土を 形成していくため, 四全総では次のような施策を体系的 に推進していくこととしています.

・安全でうるおいのある国土の形成

森林の保全や多面的利用, 河川, 湖沼, 海岸等の管 理・保全やこれらと人とのふれあい，水資源の開発・ 保全, 海洋・沿岸域の利用と保全, 自然環境や歴史的 環境の保全, 大規模地震対策.

・活力に満ちた快適な地域ゔくりの推進 
個性形成事業の推進，都市と農山漁村との広域的交 流, 都市活力の充実, 都市環境の整備, 良質な住宅・ 宅地の供給

・産業の展開と生活基盤の整備

農林水産業の振與，工業および新しい産業の地域的 展開，教育・文化の活性化，余暇・レクリエーション のための空間整備, 保険・医療・福祉施策の推進 - 定住と交流のえめの交通，情報・通信体系の整備

国土の一体化と国際交流の促進，交通体系の整備， 情報・通信体系の整備

以下では，これらの中で国土の建設という観点からの 主要施策について紹介することといたします。

\section{（1）水資源の開発・保全, 水系の総合的管理}

わが国では，水資源確保の努力が古くから行われてお り，現在では，渴水年において自然状態で利用し得る河 川流量はほとんど利用されつくした状況にあります。そ のため，人口の増加，生産活動の拡大等に伴い新たに必 要となってくる用水の確保については, 主にダム等の水 資源開発施設によって進められています。

水資源の開発は従来から，拉扮む敉 10 年に一度程度 発生することが予想される規模の渴水を対象に進められ てきましたが, 最近では, 当初予定していた発生頻度を 超えてより頻繁に渴水が発生するようになってきていま す.

また，最近の急激な水需要の増大に対して水資源の開 発が追いつかず，このため，河川水が豊富なときしか取 水できない不安定取水に頼っている都市用水が 年 間 約 30 億 $\mathrm{m}^{3}$ と, 都市用水全体の約 1 割を占めており, 渴 水による被害が頻発する原因の一つとなっています。

これに加えて，今後の給水人口の増加，生活水準の向 上による水使用量の増加，生産活動の抗大および水田・ 畑地かんがいの進展などにより, 昭和 75 年の水需要は, 58 年の 892 億 $\mathrm{m}^{3} /$ 年から 1056 億 $\mathrm{m}^{3}$ /年程度に増加す るものと想定されており，水資源の開発により水の安定

表一3 水需要の見通し

(単位: 億 $\mathrm{m}^{3} /$ 年)

\begin{tabular}{|c|c|c|c|c|}
\hline \multirow{2}{*}{\multicolumn{2}{|c|}{ ブロック }} & 水 & 要 & \multirow{2}{*}{$\begin{array}{l}\text { 昭和 } 59 \text { 75年の } \\
\text { 水需要增加量 }\end{array}$} \\
\hline & & 昭和 58 年 & 昭和 75 年 & \\
\hline 北 & 道 & 62 & 75程度 & 13程度 \\
\hline 東 & 北 & 196 & $225 "$ & $29 "$ \\
\hline 関 & 東 & 161 & $196 "$ & $35 "$ \\
\hline 中 & 部 & 155 & $183 "$ & $28 "$ \\
\hline 北 & 陸 & 46 & $53 "$ & $7 "$ \\
\hline 近 & 畿 & 95 & $113 "$ & $18 "$ \\
\hline 中 & 国 & 77 & $50 "$ & $13 "$ \\
\hline 四 & 国 & 39 & $47 "$ & $8 "$ \\
\hline 九州 - 沖 & 縄 & 105 & $127 "$ & $22 "$ \\
\hline 全 & 国 & 892 & $1056 "$ & $164 "$ \\
\hline
\end{tabular}

注 1) 水需要は, 生活用水, 工業用水, 農業用水の合計である（取水量 ヘ்ース).
的な供給を図る必要があります。

(表-3)

このような水需要の増大に対応するとともに，不安定 取水や，地盤沈下，地下水の塩水化等の障害を伴う地下 水採取を解消していくため, 長期的視点に立って計画 的，先行的に水資源の開発を進めることとしています. 特に三大都市圈をはじめ, 瀬戸内海沿岸, 九州北部, 沖 縄等の水需要がひっ迫している地域を中心に，積極的に 水資源開発を進めるとともに, 離島, 半島等で地形条件 等により通常の水資源開発が困難な地域に㧍いては，海 水淡水化，他地域からの導水，地下ダムの建設などによ り，水の安定供給の確保を図ることとしています。

さらに, 生活水準の向上, 経済社会の高度化等に伴 い，水利用と国民生活や経済社会活動とのかかわりが深 まり，渴水が発生したときの経済的，社会的影響が著し く増大しています．このための施策として, 通常の利水 容量のほかに, 異常渴水時においても社会生活を維持す るために, 必要最小限度の水を補給するための渴水対策 容量をもったダム（図一2）の整備や，河川水等の水源 を複数確保したり，水の相互利用を図る水源の複数化・ ネットワーク化, 水の循環利用の推進, 節水ルールの確 立等さまざまな対応を進めることとしています。

また，都市を中心として，豊かな水に恵まれた空間の 創出や河川浄化等のため，河川水，下水処理水等を活用 した環境用水の確保，水資源の保全の観点から，排水の 規制，下水道等の水質保全施設の整備等を進めるほか, 水源地域の森林の整備を推進することとしています.

一方，水は自然の循環経路を通じて，動植物や人間の 諸活動を支えながら，流域を形成し国土を構成してきま した．その結果，日本独特の国土と生活文化がはぐくま れてきたといっても過言ではありません．

しかしながら，近年，人口の都市集中と土地利用の高 度化により，水循環経路の機能低下，水面空間の減少， 人閒と水とのかかわりの希薄化などが進んでおり, 流域 の自然的・社会的特性をふまえつつ国民の生活・文化に 水を溶けこませ，人と水とのかかわりを再構築し，利用 と保全が調和するよう水系の総合的管理を行う必要があ

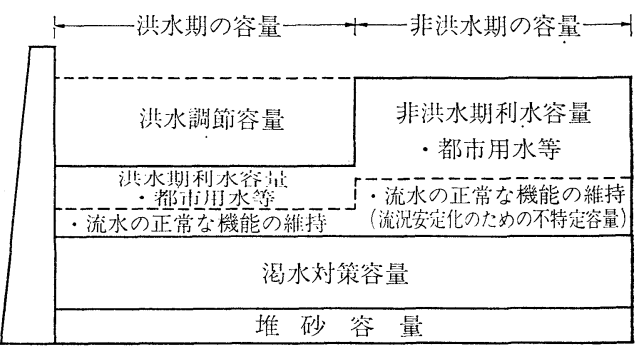

注：渴水対策容量は，通常の治水容量，利水容量の下に 通年容量として確保し, 通常の利水運用では使用せ ずに備蓄を図り，異常混水の時だけに使用する。 
ります.

このため, 水面空間・水辺空間の有するオープンスペ 一ス, 自然とのふれあい, 非常時用水の提供等の多様な 機能を複活あるいは確保するため, 水辺を生かした町つ゚ くりを進める水と緑のマスタープランを策定し, 水面, 办辺と公園, 緑地を連携させた「水と緑のネットワー ク」の形成を図ることとしています.

\section{（2）国土の保全亡安全性の確保}

都市化, 情報化の進展など経済, 社会環境の変化に伴 って, 災害の態様も著しく複雑, 多様化しています.

このため国土保全の推進, 大規模地震への対応等の災 害対策を推進する必要があります.

国土保全施設の整備水準はなお低く，また国土保全に 対する国民の要望もさらに高まってきています.

わが国は国土面積の 1 割程度の氾濫区域に人口の 5 割, 全資産の 7 割が集中しています. 特に, わが国の都 市は諸外国の都市と比べて災害に対し非常に危険な条件 下にあります。

これらの地域を含め, 国土の浸水被害の危険性を減少 させるため, 森林, 遊水池等の保全と, 多目的遊水池, ダム等による貯留方式を活用して国土保全施設の整備を 推進することとしています.

また, 治水事業についても, 流域の開発による洪水流 出量や流出土砂量の増大, 淡水氾濫原等の危険区域での 土地利用の高度化等が進んでおり，これに対応するため 大河川は戦後最大洪水, 中小河川は時間 $50 \mathrm{~mm}$ の降雨 に対応できることを当面の目標として整備を推進するこ ととしています.

わが国では，沖積平野等の低平地や山間・山麓に多く の居住地が立地しており,このような地域では, 国土保 全施設の整備とまちづくりが一体となった安全対策を総 合的に講ずる必要があります.

このため, 重要な地域を守る堤防については, 越水, 浸透，地震に対して安全性を高めるため，幅の広い高規

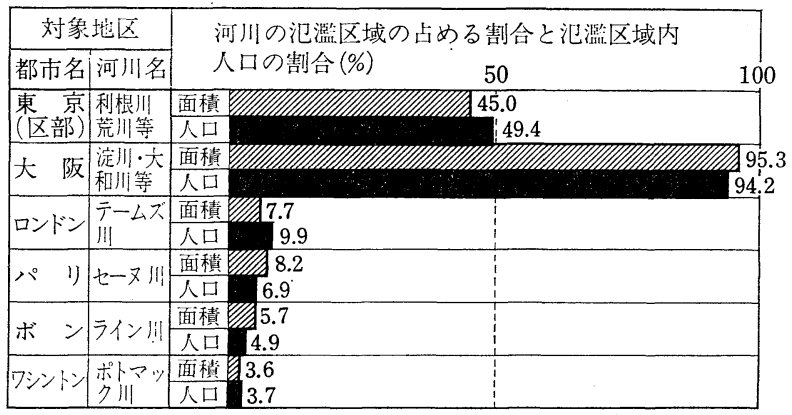

注） 1 , 建設省資料。

2. 調查年は，日本1985年，ロンドン1981年，パリ 1982年, ボン1985年, ワシントン1980年である。

図一3 世界の主要都市における河川汇濫区域の状況
格堤防の整備を進めるとともに，海岸についても，無防 備な状態にある海岸線を重点に, 戦後最大規模の高潮, 波浪等に対応した海岸保全施設の整備を推進することと しています。

これらの整備にあたっては，良好な海岸環境を求める 国民のニーズの高まりに対応するため, 多面的な機能を 有する施設の整備や，面的な防護に重点を置いた整備を 進め, 魅力ある海岸空間を創出することとしています.

また, 大規模地震等広域的な災害から国民の生命と財 産を守り, 経済・社会活動の安定性を確保するために も, 大都市圏とりわけ東京圏への人口, 諸機能の集中を 避け多極分散型国土の形成を目指すこととが重要となっ ています.

このため，各地域の防災性の向上，防災体制の充実， 電力, 交通, 情報・通信, 上下水道等のライフライン機 能のリダンダンシーの確保策等を進めるとともに，東京 圈については，震災時に首都のもつ諸機能を維持するた め, 周辺部への業務 - 管理機能の分散, 代行可能な交通 施設の整備等により広域的な人流, 物流の確保を図るこ ととしています.

また, 近年, 火山周辺地域の開発が進んでおう, 噴火 発生時の危険性が増加していることから, 周辺関連体制 の充実, 強化とともに, 交通施設 - 退避施設等の避難施 設の整備を進め避難体制の充実を図ることとしていま 于.

\section{（3）都市の活力の充実と良質な住宅・宅地の供給}

活発な都市活動を機能的に支えるとともに, 安全で快 適な居住環境を形成するため, 都市整備を積極的に推進 する必要があります.

このため, 既成市街地においては都市再開発を推進 し，都市の更新と活性化を図り，職住近接性の高い住宅 に対する需要や昭和 75 年までに約 1 万 6000 ha と見込 まれる事務所床需要への対応を図ります. 特に, 都心部 における空間の量的不足，安全で快適な空間の活用等を 進め，都市景観の改善と新しい空間の創出を 図ることとしています.

また，地域の活性化を促すためには，核と なる都市においてそれぞれの特性に応じた機 能の充実を図ることが必要となります，その ために業務，情報，国際交流等都市の中核諸 機能の受け皿となるインテリジェントビル， 国際会議場等の諸施設, 交通施設・テレポー 卜等の基盤施設の整備と人材育成やイベント の開催等のソフトな施策を進めることとして います.

また，相対的に立ち遅れた大都市圈におけ る居住水準の向上と地方定住の基盤となるよ 


\section{表一4 住宅関連指標の推移と目標}

\begin{tabular}{|c|c|c|c|c|}
\hline 項 & 単 位 & 昭和 48 年 & 昭和58年 & 昭和75年 \\
\hline 世带数（住調ベース） & 十万世帯 & 297 & 352 & 約 410 \\
\hline 住 宅 総 戸 数 & 十万戸 & 311 & 386 & 約 460 \\
\hline 1戸当たり平均床面積 & $\mathrm{m}^{2}$ & 77.1 & 85.9 & 約 100 \\
\hline
\end{tabular}

資料：総務庁「住宅統計調查」

注 1) 世带数は国勢調査ベースによる 75 年世带数を国土庁が推計し, 住宅統計調查報告べースに勘算した。

2）平均床面積と容積率は，今後の滅失・着工動向等を勘案し推計し た。

うな魅力的な生活環境の実現を図り，安定したゆとりあ る生活を実現するため，高度化，多様化する国民の居住 ニーズに的確に対応しつつ，地域の特性に応じた質の高 い住宅，宅地の供給を図る必要があります。

このため, 昭和 75 年に扔ける住宅戸数約 4600 万戸, 一戸当たりの平均住居専用面積約 $100 \mathrm{~m}^{2}$ を目標に, 21 世紀に向けて良質な住宅ストックの形成を図ることとし ています。

(表一4)

また，自然とのふれあいや余昵を重視した生活ニーズ の充足，あるいは国際化等に対応した大都市の機能的ラ イフスタイルを可能とするため, 複数住宅の利用—— ルチハビテーション一に対応する住宅の整備を各種の 助成措置を講じることにより促進することとしていま す.

さらに，計画期間における住宅建設活動に伴い新規に 必要となる住宅用地の需要約 18 万 ha に対応して, ニ ニータウン等の計画的な宅地供給を推進し，良質な宅地 ストックの形成を促進することとしています。

\section{（4）長寿社会における生活基盤の整備}

経済社会の長寿化，ソフト化，サービス化の下で，教 育，文化，余层等のニーズに対応した生活基盤整備を進 め，生涯を通じて健やかで充実した生活ができるように していく必要があります。

今後, 自由時間の増大や経済社会の複雑化を背景に学 習ニーズが高まることが予想されており, 家庭, 学校, 社会の三者が一体となった生涯学習体系を構築していく ことが重要となってきます.

また，余㗇活動に対する指向も，自然とのふれあいの ほかスポーツ, 文化, ボランティア活動など, 健康増 進, 自己啓発, 社会参加等を組み合わせた複合的, クリ エイティブなものへと変化していくことが予想されてい ます.

このため, 日常的な余既活動のための施策の充実に加 え, 長期滞在や複合的な目的に対応したレクリエーショ ンゾーン, リゾート地域等を全国に整備することとして います.

\section{（5）交通体系の整備}

交流の活発化が進む中で，交通体系の整備は各種の交
流を促進し, 諸機能の分散や地域の発展を促すための戦 略的，先行的な手段となるものです.

21 世紀に向けて各種交流手段に対する 国民のニーズ は多様化してきます．国内交通についてはその移動量が 増大するとともに高速性，利便性，信頼性等が求められ るようになり，国際交通についても移動が日常化し，利 便性の向上が求められるようになります．貨物輸送の分 野でも多様な輸送ニーズへの対応が求められるようにな ります。

交通体系の整備にあたっては，既存の交通 手段に加 え,種々の新しい交通手段を地域の特性に応じて導入し， おのおのの交通機関がそれぞれの特性を十分に発揮でき る相互補完的な交通体系の構築が必要となります.

また，空港，港湾と幹線道路あるいは高速鉄道との接 続の利便性, あるいは各地域から各交通施設へのアクセ スの強化等を図っていく必要があります.

物流の面でも, ニーズの多様化に対応して, 国内さら には国際的にも，高速性，定時性が要求されるととも に，小口高頻度化，ユニット化等質的な変化に対応した 複合一貫輸送が一層進展します.このため, 港湾, 空 港, 物流ターミナル等の物流拠点相互を連絡する幹線交 通機能の強化を図ることが重要となります.

このような要請に対応するため, 次のような点を目標 において各交通施設の整備を進めることとしています.

・大都市および地方圈における国際交通機能の強化

・全国の主要都市間を日帰り可能とし，また物流の高速 性，定時性を確保することを目的とした『全国一日交 通圈』の構築

・多重系交通網の形成による交通網の安定性の向上
a) 幹線交通体系の整備
(1) 幹線道路

高規格幹線道路網については，三全総における1万 $\mathrm{km}$ 余の構想を拡大し, 高速交通サービスの全国的な普 及, 主要拠点間の連絡強化を目標に, 地方中核・中枢都 市, 地域の発展の核となる都市およびその周辺地域か ら，お括むね 1 時間程度で利用が可能となるよう，全体 構想（計画期間 30 年程度）として 1 万 $4000 \mathrm{~km}$ のネ ットワークを形成することとしています（図一4).

これにより，国土のほとんどすべてが高規格幹線道路 に 1 時間以内に到達できるようになります（図一5).

また，10 万人以上のすべての都市がインターチェン ジにより直結され，主要な港湾，空港とは抒拈むね 30 分以内で連絡されるようになるなど, 国土の交流基盤の 均質化を大きく促進することができます.

このうち計画期間内には, 既定の国土開発幹線自動車 道 $7600 \mathrm{~km}$ (うち供用中 $3910 \mathrm{~km}$ ), 本州四国連絡橋 3 ルートの概成を含め，お抢むね 8000 9000 km の整備 


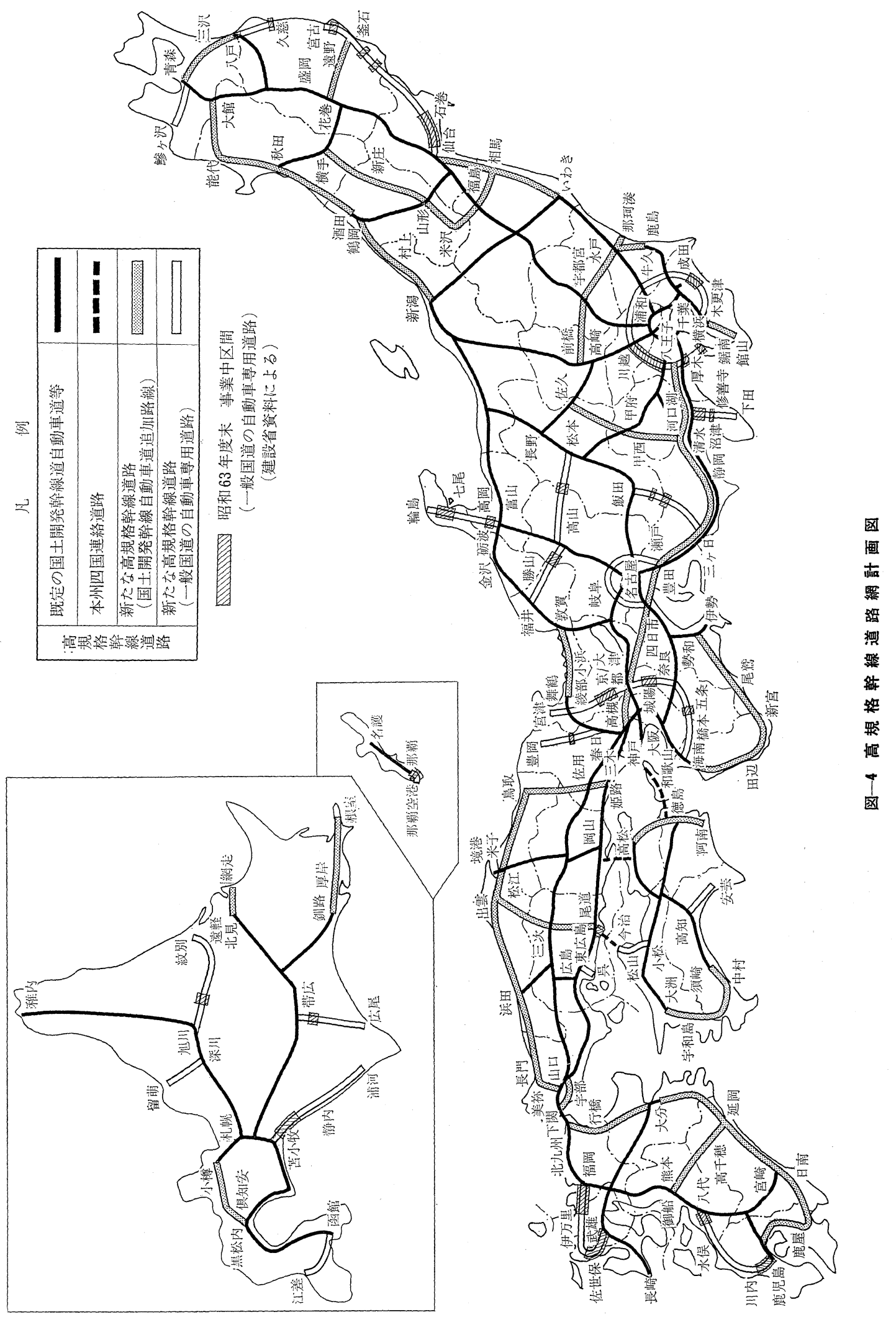




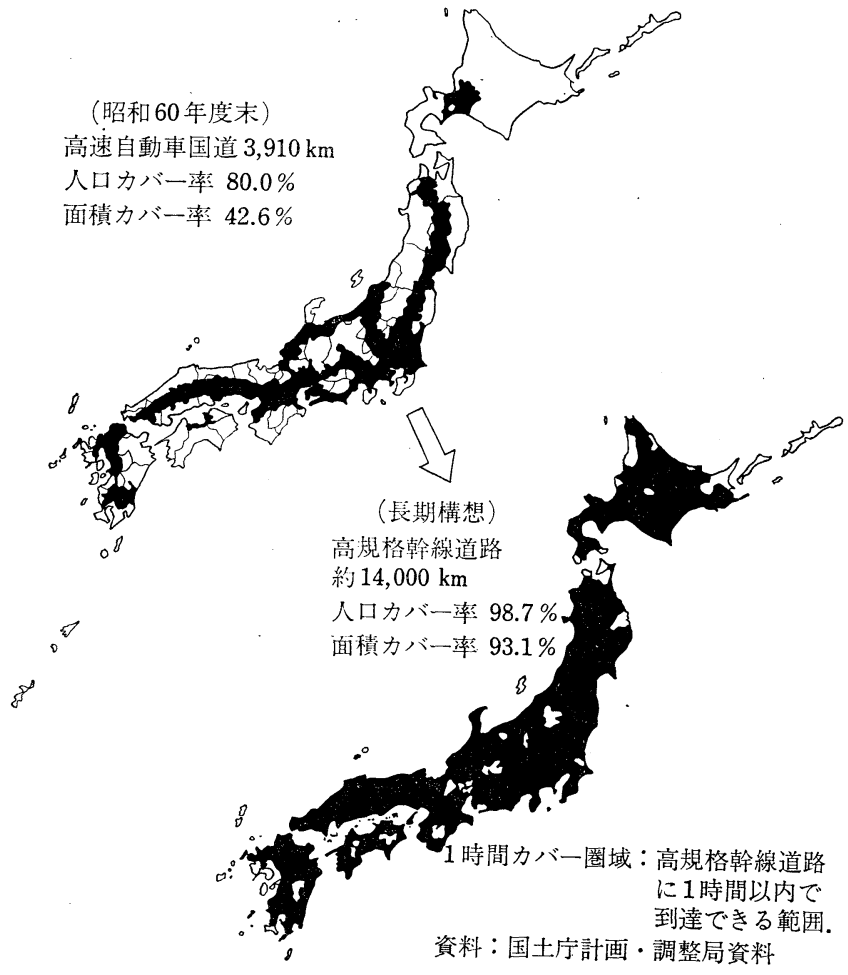

図一5 高規格幹線道路の 1 時間カバー圈域図

を進めることとしています。

(2) 高速鉄道

高速鉄道網は新幹線，磁気浮上式鉄道等によって形成 されます．このうち，高速鉄道網の骨格をなす新幹線に ついては，今後検討あるいは解決すべき事項が多くあり ますが，長期的には既定計画路線約 $7000 \mathrm{~km}$ (うち 開

凡 例

-：人口规模抢よそ 100 万人以上の都市

○：人口规模抢よそ 50 万人以上の都市

○：人口規模拉そ 30 万人以上の都市原

—: 既設新幹線

--.. : 整備計画啋幹線

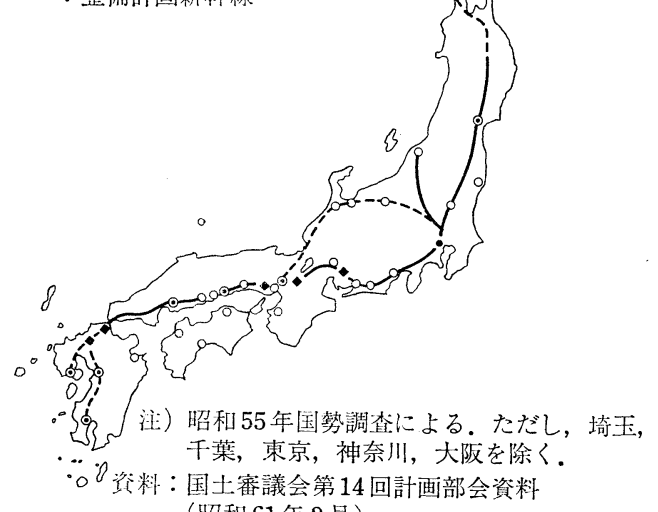

(昭和 61 年 2 月)

図一6 新幹線計画図
業 $1800 \mathrm{~km}$ ) のネットワークを基本とし， 今後の諸情勢の動向を見極めながら対処して いくこととされています.

計画路線のうち, 整備計画 5 線の 延 長は $1440 \mathrm{~km}$ ですが，このうち東北新幹線（盛 岡〜青森), 北陸新幹線 (高崎〜小松), 九州 新幹線鹿児島ルートについては工事認可申請 が出されています。

この整備 5 線とすでに開業している 4 新幹 線により，人口 50 万人以上の都市および 30 万人以上で連担した都市が結ばれ，国土を縦 貫する高速鉄道網の骨格が形成されることと なりますが，計画期間においては整備 5 線に ついて，諸事情を考慮しつつ逐次着手してい くこととしています.

(図-6)

\section{(3) 空港}

世界に開かれた国土の形成と国際社会にお けるわが国の役割を遂行していくために，今 後, 大都市圈での国際交流機能の強化と適切 な分担を進めるとともに，地方においても国 際交流機能の適切な分担を進め, 地方の活性 化を図っていく必要があります.

このため, 東京, 大阪等の国際基幹空港を 中心として全国 10 ブロックにそれぞれ一空港と, 需要 の多い大都市圈, 人口, 都市機能等の集積が複数地域に 別れるブロックの複数空港など，およそ 15 か所の空港 機能を整備し，国際交流機能を強化することとしていま 于.

国内航空網については, 現在までの空港整備や今後計 画されている整備が進むと, 基本的な航空ネットワーク が形成されることとなりますが，それでもなお空港まで 1 時間程度で到達できない空港空白地域が 残 ります.

(図-7)

これらの地域については，その中核となる地方都市 （おおむね人口 5 万人以上の都市）を中心とする，およ そ1時閒圈域（全国でおよそ 50〜70 地区）に成立可能 性を検討の上コミューター航空の導入を進めることとし ています.

計画期閒中には関西国際空港, 新東京国際空港, 東京 国際空港の沖合展開事業等の完成を図るとともに, 全国 の主要な空港の拉充, 整備を進め, 国際交流 機 能の強 化，地方圏との航空サービスの拡充を図ることとしてい ます.

また, 地方圏においては航空需要の増大, 高速サービ スへの要請等に対応するため,空港の大型化, ジェット化 のための整備を進め, 空港空白地域についても必要に応 じてコミューター航空の導入を図ることとしています. 
凡例

- 既設空港

】計画空港(第 5 次空港整備事業 5 箇年計画 による)

(III) 筀港からの 1 時間圈域

他の高速交通体系については, 四全総本 文の記述での計画期間中の整備がなされ ている場合を仮定している.

なお,沖縄県および島しょ部は除いている。

資料：国土庁計画調整局資料

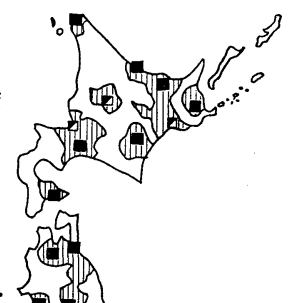

宛

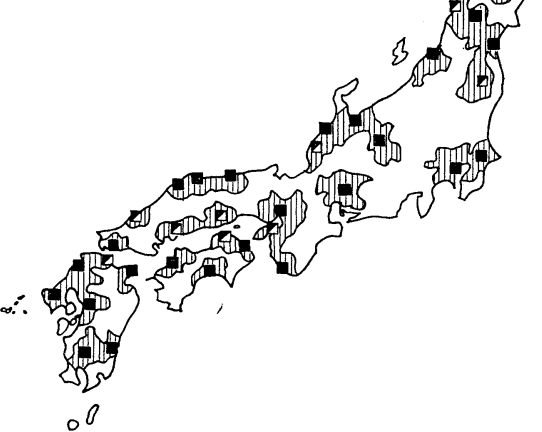

図一7 空港からの 1 時間圈域（将来）

(4) 港湾

本格的な国際化の進展, 産業の国際水平分業の進む中 で, 国際貨物流動は半製品, 製品の輸送量が増大すると
ともに，高付加価值化，軽量化が進みコンテナ 輸送が引き続き増加することが予想されていま す.このため, 三大湾, 北部九州, 日本海中部 沿岸等おおむね 15 地区の扰点的な港湾におい て, コンテナ輸送等国際交通機能の拡充を図る こととしています.

この結果，全国どの地域からもおおむね 4 時 間以内 (100 $200 \mathrm{~km}$ 圏) で外貿拠点港湾に 到達可能となります.

また, 国内海上輸送についても, 発地から着 地まで各種の交通機関を組み合わせて貨物を輸 送する複合一貫輸送の進展により，コンテナ等 のユニットロード輸送が進展することが予想さ れています.このため, ユニットロード輸送の 基幹となるおよそ 30 地区の港湾で, 太平洋, 日本海等の沿岸を有機的に結合する全国海上輸 送網を形成することとしています.

これによりわが国沿岸部におよそ 100〜200 $\mathrm{km}$ の間隔で内航の拠点となる港湾が配置さ れ，各地からこれらの港湾におおむね 2 時間以 内で到達することが可能となります.（図一8)

また，海上輸送の安全性と定時性を確保する ために，全国各地において必要に応じ避難港，航路等の 整備を進めるとともに，近年のニーズの多様化に対応で きるような総合的な港湾空間を創造していくこととして

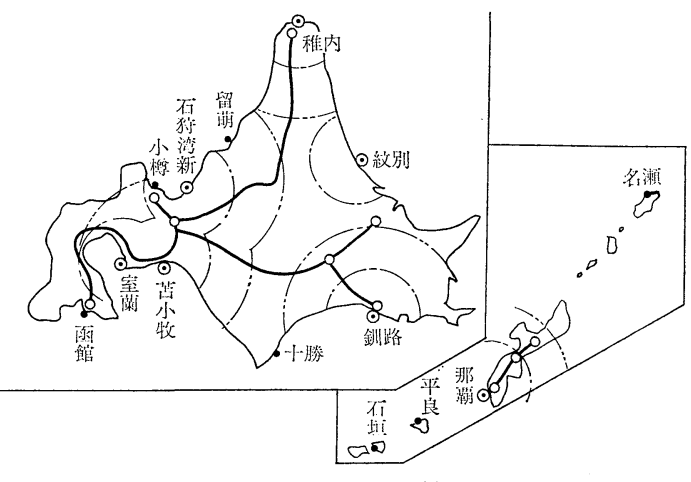
注）図中の円弧は，拠点港を中心とした おおむね半径 $50 \mathrm{~km}$ および $100 \mathrm{~km} の$ 範囲を示している。

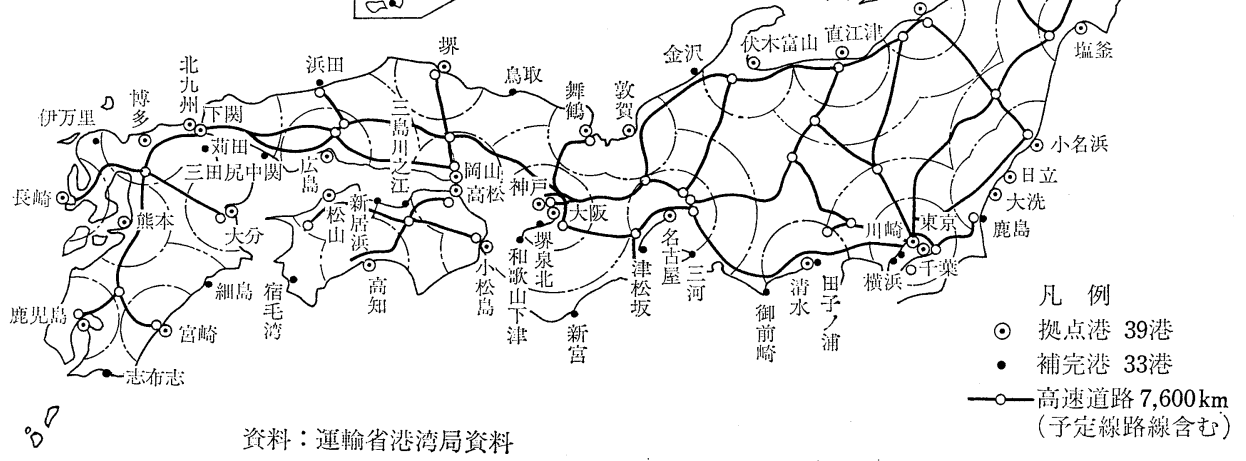


います．さらに，地域の活性化を図るために各地域との 交流，連携を考慮したマリーナ，観光船ターミナル等の 整備を促進することとしています.

b) 地域交通体系

(1) 大都市圈の交通体系

大都市圈では, 幹線交通とのアクセスの改善, 鉄道の 混雑，道路の啮滞の緩和，核都市等周辺地域の育成を促 進し, 特に東京圈では都心一点集中構造の改善を促すこ とを重点に交通施設の整備を進めることとしています.

鉄道は，常磐新線など都心付近から放射方向の路線の 新設, 複々線化等の線路増設, 環状路線の整備等を進め るとともに，鉄道駅を各種公共サービスや情報サービス 等の機能を備えた複合ターミナルとして整備し, 移動の 合理化，交通流の安定化を促進させる計画です.

道路については, 幹線交通へのアクセス路線, 環状路 線, 都市内の主要拠点および新たな発展の核となる拠点 を相互に連絡する路線に重点を置き，基幹的な道路の整 備を進める計画です。

また，交通機関相互の連絡性を改善するため, 空港ア クセスの整備, 駅前広場など駅周辺の整備, 鉄道の相互 乗り入れ等を進めるとともに，機動性の高い交通手段を 確保するため, 河川, 運河を利用する水上バス, 都心部 におけるへリポート等の整備を進めることとしていま す.

\section{(2) 地方都市圈等の交通体系}

地方の中心都市での安全で快適な交通環境の形成と, 周辺地域におけるモビリティの確保が地方都市圈の交通 の課題です.このため, 公共交通機関の活性化と道路混 雑の緩和, 幹線交通施設と都市あるいは都市周辺地域と の連絡の改善の二つを重点に交通施設を整備することと しています.

まず，公共交通機関の活性化のため，鉄道について は，新駅の設置，列車の増発，速度向上あるいは新幹線 との接続の改善等，地域に根ざしたサービスの提供によ り，利便性の高い鉄道輸送の実現を目指しています。

さらに, 都市の規模や特性に応じ, 地下鉄, 新交通シ ステム等の導入を検討すること, 乗り継ぎ施設の整備に より, 鉄道, バス, 二輪車, 乗用車等の交通機関相互の 連絡性の改善をめざしています。

道路については, 円滑な道路交通を確保するため, 基 幹的な道路は, 幹線交通施設と都市周辺地域を連絡する アクセス道路や，通過交通を排除するためのバイパス， 環状道路に重点を置きつつ整備を進めることとしていま す.また，泾滞の激しい交差点の立体化，道路と鉄道の 連続立体交差化，市街地での安全で快適な歩行者空間を 確保するためのゾーンシステムやトランジットモール等 の導入を促進することとしています.

\section{3. 四全総と内需拡大}

\section{（1）国土基盤投資の規模}

\section{a） 国土基盤投資の概念}

四全総では，国土の総合開発に不可欠な国土保全，水 資源, 交通, 情報 - 通信, 電力, 住宅, 学校, 病院等の 国土基盤について，国，地方公共団体等が行う公共投資 （狭義の国土基盤投資）に限らず，民間投資の一部を含 めた投資の規模と投資の考え方について示しています.

従来は公的主体による投資をもって国土基盤投資と考 えるのが一般的であり，1つの整理の仕方として妥当性 をもっていました。

しかしながら，近年国鉄，電電公社等の民営化，公共 的事業分野への民間活力の導入が進むなど，国土基盤整 備におるるる民間投資の役割が大きくなっています。

このような背景のもとに，わが国の国土基盤投資を官 民あわせたものとして捉えるほうが実際的であると考え られることから，四全総に拉いては，国民経済計算ベー スの公的総固定資本形成に民間住宅投資およびエネルギ 一, 交通, 情報・通信, 学校, 病院等の分野にかかわる 民間企業投資を加えたものを『広義の国土基盤投資』(以 下国土基盤投資という）と定義し，その投資額，投資の 考え方等について示しています.

\section{b）経済と投資の規模}

昭和 50 年代の実質経済成長率はおお抒む $4 \%$ 程度と 比較的安定した動きを示しており，昭和 60 年度の国民 総生産は 293 兆円（昭和 55 年価格）に達しています.

四全総では経済の規模について, 『内需主導による中 成長が維持されることを前提』としています。

経済成長率については, 円高の行方, 産業構造の急速 な変化などから，その先行きは不透明といわざるを得ま せん.

しかし，世界経済はこれからも全体として緩やかな成 長が見込めるであるうと考えられています，また，産業 構造の変化の中で順調な拡大をみている産業があるほ か，技術革新，情報化を背景に，新たなリーディング産 業の出現も期待できる状況になっています，さらに，昭 和 50 年代において，わが国は石油危機およびこれに端 を発した産業構造調整の中で $4 \%$ 程度の成長を実現して います.

このようなことから，わが国経済は今後もある程度の 成長が持続することが期待できるものと考えられていま す.

一方，わが国の国土基盤は欧米に比べその整備水準が いまだ遅れており, 引き続き整備に努める必要がありま す.また，これまでの輸出主導型の成長に対して, 諸外 国から批判が出ており，内需桩大に対して強い要請がで 
ています.

これらの点をふまえ, 四全総ではわが国の経済成長が 内需主導による中成長が維持されることを前提に, 昭和 75 年度の経済規模を 500 兆円台（昭和 55 年価格）と 想定しています.

昭和 60 年度の実質 GNP は 293 兆円で, これが 75 年度に 500 兆円台となるためには，4\% 程度の成長率が 必要であり, 仮に, 経済成長率を $4 \%$ としますと 75 年 度の GNP は 530 兆円程度となります.

また, 61〜75 年度の 15 年間の 実質 GNP の累積額 はおよそ 6000 兆円強と推定されます.

昭和 50 年代の GNP に占める総固定資本形成の割合 は $1 / 3$ 程度であり, 仮に将来もこの比率が続くものと想 定すれば, 61〜75 年度の実質総固定資本形成の累 積 は およそ 2000 兆円程度と見込まれます.

このうち，官民あわせた国土基盤投資の規模は推計方 法によりかなりの幅がありますが，おおむね総固定資本 形成の 5 割〜 6 割程度と考えられます. このような考え 方と, さらに, おが国の経済の規模がこれまでも扡大し てきたこと, 今後もある程度の成長が見込まれること, 今後のわが国の経済運営が外需主導から内需主導を基調 として進められようとしていること, 四全総の実現に向 けて相当な額の国土基盤投資が必要であることなどを考 慮し, 経済全体のバランスを損なうことのない総投資規 模として，61〜75 年度の国土基盤投資の累積額をおお むね 1000 兆円と想定したものです.

\section{（2）国土基盤投資の重点}

\section{a）投資の考え方}

四全総の計画目標を達成するためには, 公的部門と民 閒部門の連携を図り，計画奏現のための主要施策に沿っ て国土基盤投資を積極的に推進することが必要です.

このため, 公共投資により整備される国土基盤につい ては, 着実で安定的な規模の拡大を図るため, 建設・維 持コストの低減, 受益者による費用負担の適正化等を図 りつつ, 所要の財源を確保していく必要があります.

民間あるいは官民連携して整備される部門について も，民間活力の発揮できるような種々の環境条件の整備 を進めることが重要となります.

さらに，地方圈の重点的な整備を進め多極分散型国土 の構築を促進するため, 国土基盤投資を地方圏に適切に 配分していかなければなりません.

また, 長期間の利用に耐え, 維持・更新も技術的に容 易なものにするなど, 良質で総コストが低廉な国土基盤 の形成に努めるとともに，既存のストックについてもニ 一ズの変化に対応できるよう, 点検, 改造する必要があ ります.

これからの国土基盤投資にあたっては，このような考
え方に基づき, 本格的な高齢化の時代を迎える 21 世紀 までに, 質の高い国土基盤を整備しておく必要がありま す.

b）国土基盤投資の重点

四全総では, 多極分散型国土の構築のための基本戦略 として『交流ネットワーク構想』を掲げており, 地域主 導による地域づくりを推進するとともに，そのための基 盤として交通，情報・通信体系の整備を推進することと しています.

また, 計画の基本課題として「定住と交流による地域 の活性化」「国際化と世界都市機能の再編成」「安全で 質の高い国土環境の整備」を揭げています.

これらの考え方をうけて, 地域の活性化の推進, 世界 に開かれた国土の形成, 安全でうるおいのある居住空間 の形成，交流の円滑化による国土の一体化等にかかわる 施策を重点施策として位置づけ，積極的な投資を進める こととしています.

(表-5)

\section{表一5 国土基盤投資の重点施策}

\begin{tabular}{|c|c|}
\hline 視 & 点 施 \\
\hline a. 地域の活性化 & 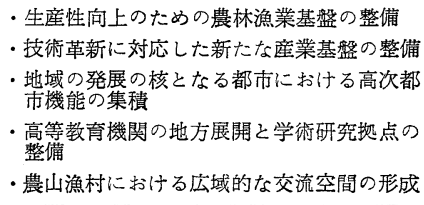 \\
\hline $\begin{array}{l}\text { b. 世界に開かれた国土 } \\
\text { の形成 }\end{array}$ & $\begin{array}{l}\text { •特色ある国際交流拠点の形成 } \\
\text { •国際化に対応した空港, 港湾の整備 }\end{array}$ \\
\hline $\begin{array}{c}\text { c. 安全でらるおいのあ } \\
\text { る居住空間の形成 }\end{array}$ & 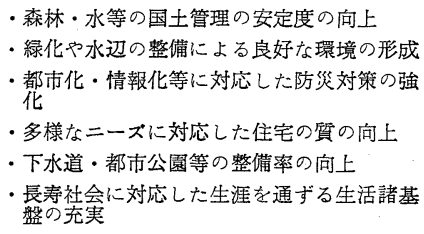 \\
\hline $\begin{array}{c}\text { d. 交流の円滑化による } \\
\text { 国土の一体化 }\end{array}$ & $\begin{array}{l}\text { ・全国主要都市間を連絡する高速交通体系の } \\
\text { ·效率的な物流体系の整備 } \\
\text { ・高度な基幹的情報・通信体系の全国展開 } \\
\text { •地域におけるお交通, 情報・通信基盤の強化 }\end{array}$ \\
\hline
\end{tabular}

表一6 戦略プロジェクト

\begin{tabular}{|c|c|}
\hline 分 & 戦略プロジェクト \\
\hline $\begin{array}{l}\text { a . 地域産業振興プロジ } \\
\text { ×クト }\end{array}$ & $\begin{array}{l}\text { - 産業・技術拠点の形成 (研究開発・人材育 } \\
\text { 成等新しい産業の育成) } \\
\text { •大規模高生産性農地の整備 (ほ場の大区画 } \\
\text { 化, 沉用田化等) } \\
\text { ・大規模なリゾート地域の整備 }\end{array}$ \\
\hline $\begin{array}{l}\text { b. 都市整備, 国際交通 } \\
\text { のプロジェクト }\end{array}$ & 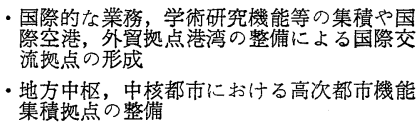 \\
\hline $\begin{array}{l}\text { c. 国内の基幹的交通, } \\
\text { 情報・通信体系の整 } \\
\text { 備 }\end{array}$ & $\begin{array}{l}\text { ・高規格幹線道路の整備 } \\
\text { ・空港の整備 } \\
\text { ・整備新幹線の逐次建設着手 } \\
\text { ・サービス総合ディジタル網の構築 }\end{array}$ \\
\hline
\end{tabular}


また，重点施策の中で，多極分散型国土を構築するた めにとりわけ重要なプロジェクトとして, 地域開発の機 動力となり交流ネットワーク構想の展開を先導する施策 を「戦略プロジェクト」として位置づけています。

戦略プロジェクトの国土基盤投資全体に占める割合は それほど大きくはありませんが，多極分散型国土を構築 するための戦略的重要プロジェクトとして位置づけ，官 民の総合的努力により計画期間中に確実に推進すること としています.

(表一6)

\section{（3）四全総の推進と内需拡大}

わが国の経済運営は，これまでの外需主導型から内需 主導型へ，資本輸出型から国内投資型への転換が強く要 請されています。

内需主導の持続的な安定成長を図るためには, 国内の 余剩資金を国内の投資に回し，国際的地位にふさわしい 経済運営を進める必要があります.

また，わが国経済は，急激な円高に伴う経済構造調整 の進行, 国際化，情報化の進展が進むなかで，東京圈一 の諸機能の一極集中によるさまざまな弊害と, 輸出型企 業や構造不況業種に依存する企業城下町を中心とした地 方の疲弊が大きな問題となっています.

このため, 地方の活性化を強力に進め, 雇用機会の増 大を図っていくことが重要な課題となっています.

このような情勢の中で，公共投資を中心とした国土基 盤投資の役割はますます重大となっています.

四全総ではこれまで述べましたように，昭和 61 年度 から 75 年度の 15 年間の国土基盤投資の累積額をおよ そ 1000 兆円と想定しています.

昭和 60 年度の広義の国土基盤投資の規模は 45 兆円 程度で，その内訳は，拉よそ公的固定資本形成 21 兆円， 民間住宅投資 14 兆円，民間企業設備投資に含まれるも の 10 兆円となっています，なお，旧国鉄，旧電々公社 2 社の投資額はこれまで国土基盤投資の $6 \%$ 程度を占め ていましたが，民営化によりこの分だけ公的部門の比率 が下がり，民間部門の比率が上がることとなります。

昭和 60 年度 45 兆円であった国土基盤投資が昭和 61
〜75 年度の累積額で 1000 兆円になるためには, 年平 均実質 $5 \%$ 強の投資の伸びを確保していくことが必要と なりますが，この投資の伸びを確保することは，四全総 の主要施策の実施による計画の実効性確保と, 内需主導 による安定した経済成長の確保のための重要なポイント となるものです.

国土基盤投資は，国民生活と直接，間接に関連する基 盤整備のための手段であると同時に，その波及効果を通 じて経済全体の動きに大きな影響を与えるむのです.

国土基盤投資による内需拡大効果には，これらの投資 が建設事業を通じてさまざまな産業に新しい需要を誘発 していくといら効果と, 基盤施設が整備された後にそれ らが利用されることにより，地域内あるいは地域間の交 流が拡大し，地域が活性化していく，それにより国民経 済全体が発展していくという二つの面があります。

国土基盤投資にあたっては，地域の活性化を図り四全 総の目標である「多極分散型国土の形成」を促進すると ともに, 当面の内需拡大の要請に応えられるプロジェク 卜に対し，先行的，重点的に投資していくといら考え方 が必要です。

国土基盤投資のうちの公共投資は, 各種計量モデル分 析の結果によりますと，一般的に減税とか社会保障等の 政策手段よりも乗数効果が大きい，つまり GNP の拡大 効果, 内需拡大効果が大きいと推計されています.

(表一7)

特に, 公共投資は地方の需要払大に大きな比重を占め ており,地方の経済活動に大きな影響を及ぼすものです.

公共投資の地方への配分は, 昭和 40 年代半ばから 50 年代半ばにかけて年々増加し, 地方圈での経済の拡大や 人口の定住が進みました. しかし，50 年代半ば以降財 政再建のため公共投資が抑制されたことにより，地方圈 への公共投資のシェアは今までとは逆に年々減少し，公 共投資への依存度が相対的に大きい地方では経済活動に 大きな影響を受け, 定住化が進んでいた地域で再び人口 が減少し三大都市圈への人口流入が増加してきました。

(図一9, 10)

表一7 各 政 策手段の 乗 数効果

\begin{tabular}{|c|c|c|c|c|c|c|c|c|c|c|c|c|c|c|}
\hline \multirow{2}{*}{$\begin{array}{l}\text { 不 } \\
\text { 多時 } \\
\text { 卜 点 }\end{array}$} & \multicolumn{3}{|c|}{ 日経 NEEDS モデル } & \multicolumn{3}{|c|}{ （財）電力中央研究所モデル } & \multicolumn{3}{|c|}{ 興銀マクロモデル } & \multicolumn{2}{|c|}{$\begin{array}{l}\text { 経済企画庁 SP-18 } \\
\text { モデル }\end{array}$} & \multicolumn{3}{|c|}{ 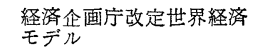 } \\
\hline & 公共投資| & 減 税 & 社会保障 & 公共投資 & 減 税 & 社会保障 & 公共投瓷 & 減 税 & 社会保障 & & 公共投資 & & 公共投資| & 減 税 \\
\hline $\begin{array}{l}46 \\
\text { 年 } \\
\text { 度 } \\
\end{array}$ & 1.8 & 1.3 & 1.1 & 2.45 & 0.67 & 0.60 & 1.34 & 0.52 & 0.46 & 42 年度 & 1.66 & & & \\
\hline $\begin{array}{l}49 \\
\text { 年 } \\
\text { 度 }\end{array}$ & 1.6 & 1.3 & 1.1 & 2.01 & 0.56 & 0.49 & 1.31 & 0.50 & 0.45 & 45年度 & 1.52 & & & \\
\hline $\begin{array}{l}52 \\
\text { 年 } \\
\text { 庋 } \\
\end{array}$ & 1.8 & 1.3 & 1.2 & 2.16 & 0.60 & 0.53 & 1.31 & 0.50 & 0.43 & 51年度 & 1.34 & 51年度 & 1.47 & 0.47 \\
\hline $\begin{array}{l}57 \\
\text { 年 } \\
\text { 度 }\end{array}$ & 1.51 & 0.87 & 0.72 & & & & & & & & & & & \\
\hline
\end{tabular}

注 1）名目 GNP に対する第 1 年目の値. 


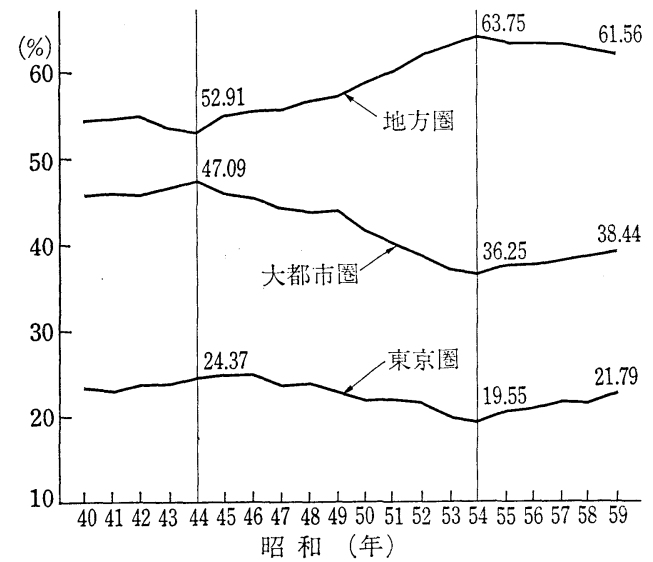

東 京 圈: 東京都, 神奈川県, 埼玉県, 千葉県。

大都市県 : これに愛知県, 三重県, 大阪府, 京都府, 兵庫県を加えた值である。

注）自治省行政投資実績による。

\section{図一9 地域別行政投資シェアの推移}

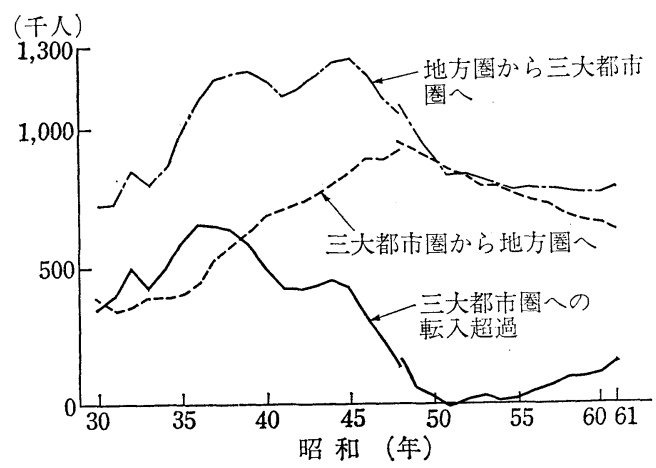

図一10 三大都市圈への人口移動

経済企画庁が地域別の公共投資依存度と経済成 長の関係を分析した結果により，公共投資による 国土基盤の整備がその後の地域の経済成長にどの ような影響を及ぼしたかについてみますと，比較 的公共投資が活発に行われた昭和 52 年度から 55 年度までの 4 年間とその後の 59 年度までの 5 年 閒との比較で，公共投資依存度の高い道県では， その比率の低下とともに成長率が下がり，公共投 資依存度の低い 3 大都市圈では成長率が高くなっ ています。

(図一11)

公共投資依存度の高い地域の産業構造をみます と, 公共投資と関連の媣い土木・建築部門の割合 が高く, 総生産額に占める公共投資の割合は北海 道で $8 \%$, 東北 $7 \%$, 沖縄 $10 \%$ と関東, 近畿, 中部の $3 \%$ 前後に比べかなり高く, 地域内の景気 扡大あるいは経済成長の公共投資への依存度が高 い地域であることがわかります。

また，公共投資の雇用誘発効果についてみて も, 地方圈において相対的に大きな雇用効果を有

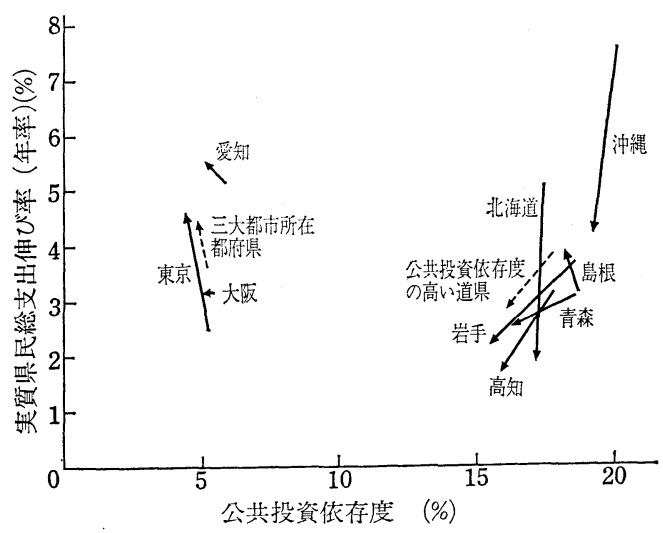

(備考) 1. 経済企画庁「昭和 62 年度年次経済報告」

2. 公共投資依存度は, 県内総支出に占める公的総固定 資本形成の割合である。

3. 公共投資依存度の高い県とは， 52〜 55 年度平均の 公共投資依存度が $15 \%$ 以上の 11 道県 (北海道, 青 森, 岩手, 秋田, 新潟, 鳥取, 島根, 高知, 宮崎, 鹿 児島，沖縄）である。

4. 岩手県については, 実質県民総支出が不明のため実 質県内総支出を代用した.

5. 矢印の基点は $52 \sim 55$ 年度平均の公共投資依存度お よび $52 \rightarrow 55$ 年度実質県民総支出伸び率(年率)であり， 終点は 55 59 年度平均の公共投資依存度および $55 \rightarrow$ 59 年度実質県民総支出伸び率 (年率) である.

\section{図一11 公共投資依存度と経済成長}

しており，公共投資は地方における当面の需要拡大，雇 用の誘発に大きな役割を果たしていることがわかりま

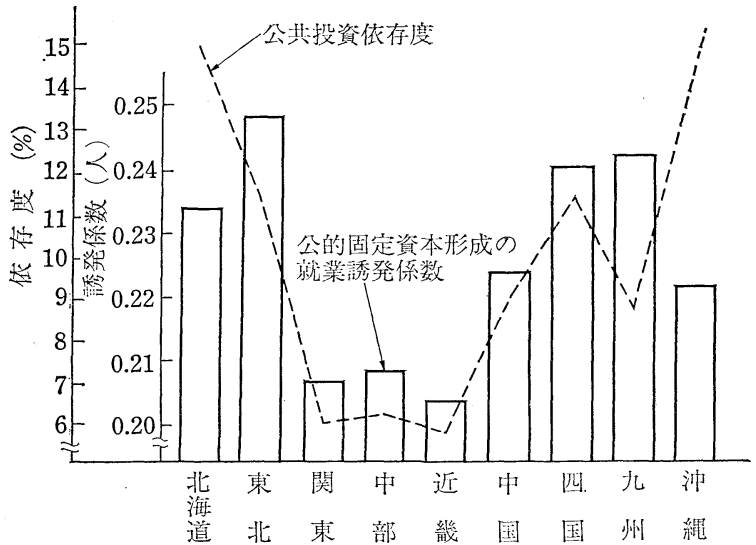

注）1. 建設省資料．原データ：建設省「昭和 55 年建設部門地域間産栄関 連表」。

2. 就業誘発係数については, 100 万円（55年価㭲）当たりの瞬発就菜 者数を示市。

3. 公共投資依存度とは，県民総生産（名目）に山㞻公的国定资本 形成の割合のことである。

4. 東北，関東，中部，近畿の対象地域は以下のと扔り。 東北: 青森, 岩手, 宮城, 秋田, 山形, 福舅 関東：茨城，杤木，群馬，埼玉，千葉，東京，神㞃川，新鼬， 山梨, 長野, 静岡.

中部：愛知，岐㚖, 三重, 算山, 不川

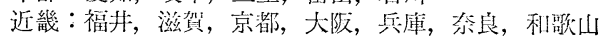


す.

このように, 内需の拡大, 地方経済の活性化を進め多 極分散型国土を形成していくうえで，公共投資の果たす 役割，公共投資を含む国土基盤投資の果たす役割といっ てもよいと思いますが，は非常に重要なものです.

このため，四全総では国土基盤投資の着実で安定的な 規模の拡大を図るため, 建設・維持コストの低減, 受益 者負担の適正化等を図りつつ所要の財源を確保するとと もに, 地方圈の重点的な整備により多極分散型国土の構 築を促進するため, 公共投資を地方圈に適切に配分する こととしています.

また，国土基盤投資にあたっては，公的部門と民間部 門の密接な連携により公共投資と民間投資とが整合した 効率的な地域開発を進めることが必要であり, このため に, 必要な法制度の充実, 民間投資を促進するための規 制緩和，地方圈においても民間活力の活用を促進するた めの政策金融・財政上の支援措置等を進めることとして います。

\section{おわりに}

四全総で想定した 1000 兆円に掠よぶ国土基盤の整備 をこれから進めるにあたって, 四全総の目的である多極 分散型国土の形成に有効でありかつ波及効果の大きい国 土基盤投資を先行的, 重点的に実施していくことが，内 需の搪大を進め国際的にも調和のとれた経済運営を図る ことにつながるものです，また，国民生活とか経済構造 を質的に高度化していくためには, 国土基盤整備を積極 的に進め 21 世紀の新しい時代に対応できるような国民 の資本を増強しておく必要があります.

本格的な高齢化社会を迎える 21 世紀には, 急激に增 大する高齢者対策, 労働力人口の減少と高齢化等から, 国土基盤のストックを充実させるための投資余力は確実 に低下することが予想されています，また，21 世紀ま でに整備される国土基盤のストックも増加し, 今後これ
らのストックの維持・更新のための費用も飛躍的に増大 することが予想されています.

21 世紀までの残された期間は, 就業人口もほとんど 減少せず投資余力も十分あり，国土基盤を充実させてい くうえできわめて重要な時期となります.

労働力や投資力に余力のあるこの時期に, 明日の時代 の活力の基盤となる国土基盤整備を先行的に進めておく ことが必要となるわけです.

21 世紀の新しい時代に向けて，このような考え方に 基づいて国土基盤の整備が先行的に進められることによ り, 全国的に人口, 産業その他諸機能が分散し, 全国に わたる交流の促進, 定住の場であり交流の場である地域 の整備と活性化が進み，『安全でうるおいのある国土の 上に, 特色ある機能を有する多くの極が成立し, 特定の 地域への人口や経済機能, 行政機能等諸機能の過度の集 中がなく, 地域間, 国際間で相互に補完, 触発しあいな がら交流している多極分散型の国土』が形成されること となるわけです.

\section{主な参考文献}

1) 経済企画庁編：昭和 62 年版, 経済白書一進む構造転換 と 今後の課題一, 1987.6.

2) 経済企画庁総合計画局編: 社会資本整備の新たな展開 -21 世紀一の新たな展開一, 1987.6.

3）建設省編：昭和 62 年版国土建設の現況, 1987.

4) 国土庁編 : 第四次全国総合開発計画, 1987.6.

5）国土庁計画・調整局編: 日本 21 世紀への展望, 1984. 11.

6）国土庁計画 - 調整局編：重点的，効率的な国土基盤投資， 1983.6.

7）自治省大臣官房地域政策課編：行政投資実績，1987.6.

8）竹内良夫編：日本の社会資本, 鹿島出版会, 1967.

9）中島富雄編：公共投資一その理論と実際ぎょうせい， 1982.1.

10）御巫清泰・森杉寿芳：社会資本と公共投資，技報堂出版, 1981.5 .

(1988.2.15 受付) 